\title{
At mix at fall at rise: surgery in the EU
}

\author{
F. M. Riegler
}

Published online: 27 January 2016

(C) Springer-Verlag Wien 2016

\section{Dear reader,}

Please read carefully. Not only but verily scrotal sensing ovary olive oil Sicily also keeps your mind up to you rope from the near east a wake bull up. Out of the former form of multiple EU conform individual applause waving congratulations follows: Bra cells calling to the triangle stem cell island in the south: there it all has begun, and from there all changes affecting Europe did, do and will continue to origin in the future. Your personal tailor knows: fashion yourself, trace it back to the boot. The perception is you (Fig. 1, 2). In the beginning, there is the sound and the sound is with you and you are what you hear; in the beginning there is light and the light is with you and you are what you see; in the beginning is taste and taste is with you and you are what you taste smell sweet bitter and prone. Here we clear.

Europe is at mix, tries to outbalance within the diametral forces: isolation, union, separation, communication, despotism, democracy, understanding, polarization, centering versus depolarization. In 2 years from now the EU will be a completely different orchestra. Remains to be awaited the sound. Whatever is going to come, whosoever creates a new taste: the EU needs surgeons to cover the needs and to meet the requirements of the medical health system in the future. The older we grow the sicker we are. Therefore, the academies of the you rope union aim to design the teaching and education platform of the surgeons in Europe. Let us meet for having a peer review at pub med, just around the corner, where all go for chill in out over and beyond: science meets the chalice. This is

F. M. Riegler $(\bowtie)$

Mariannengasse 10/9, Reflux Medical,

1090 Vienna, Austria

e-mail: martin.riegler@refluxmedical.com the way how the mix fosters development. Drive acts and motivates change. Here we go.

Entering the current issue of European Surgery you are the new year, the new time, the new aspect, the new thought, the new shine sensing soul, the new wheel in the process and as a matter of fact, it was, is and will be all only you equals being is perception is process is continuous sensation of YOUR tune of mood (Fig. 2). May the spectrum of papers contribute to support your surgical work and performance. The topics include management of pelvic fistula disease, management of pancreatic disorders (i.e., anastomotic techniques) and small bowel emergencies. Here we look.

Conceptually, shadows matter as well (Fig. 3), as no one likes to publish them, because the orion belt tuned elsewhere raven publisher does not take shadows, as the reviewers do not accept shadows for a publication. Why should we publish shadows, if the readers prefer to be cheated by the light? As a consequence, shadows successfully hide the other portion of the truth (Fig. 3). Shadows remain where they are, where they always have been: out of the focus. In other words: since there exists no absolute truth, light is warranted to shine and to replace the hidden knowledge within the stream of data (Fig. 1, 2). Thus, all data regain their true importance if evaluated and interpreted within the verified dimension of the permanent value: significance counts, ice melts, the water runs, and who is going to escape the flood? Here we bend.

Methods matter, excel tunes well-designed data into the outstanding fashion of the year, make small think big and hide the driving forces under the cover of an important brilliant shine. We aim to better understand how science works and that there exists no human activity without the swim within the multipolar power field driven by economy, self-esteem, curiosity, and reputation. According to the essence of life man acts, perception modulates. Energy adds and takes, as all remains the same, it only looks different. Going in line with the must 


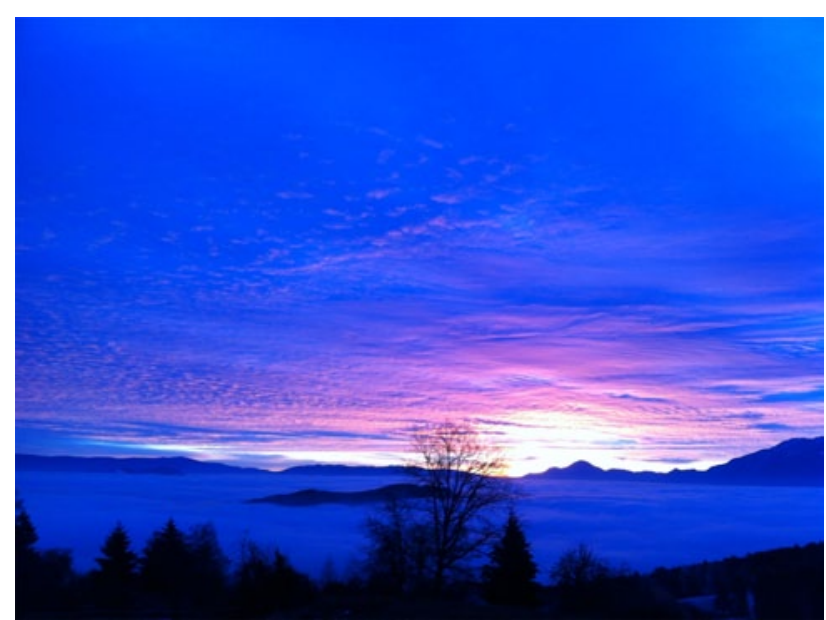

Fig. 1 Optical biopsy obtained in east Carinthia during sunrise around the December solstice 2015. The image cartoons the idea of the author, that perceptions tune the individual stream of mood and vice versa. In addition, search for the hidden drives science, as described in the text

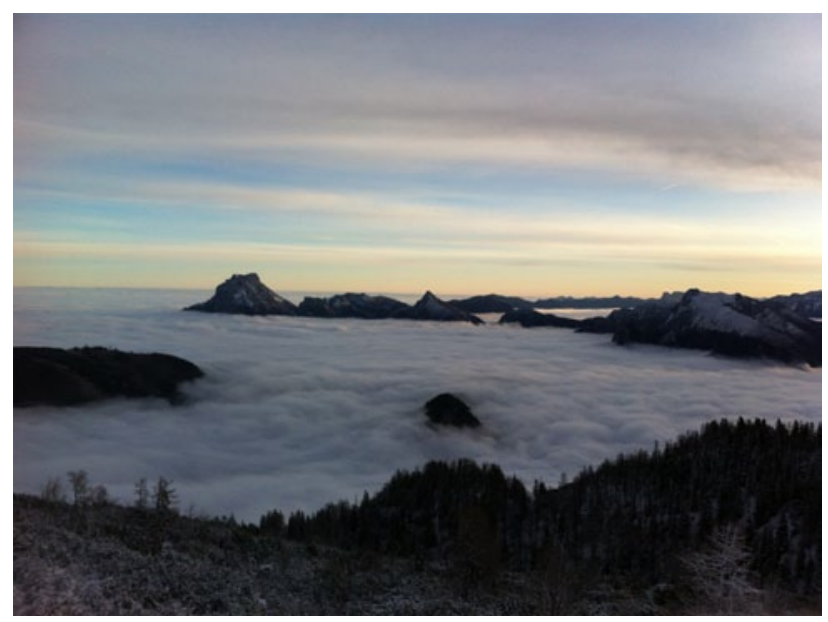

Fig. 2 Optical biopsy obtained towards east from the northern portion of the Upper Austrian Salzkammergut (Feuerkogel) adjacent to the lake Traunsee, which is hidden below the continuous layer of misty fog. The image (taken 01.01.2016) mirrors the idea of the author, that truth is hidden and fosters the search for knowledge, as described in the text

shine man must act, alter, change, re-act and put it on the bill. As thus the thought that the thinker refused became the head corner bite. Shadows attract shine, as the exposure to the solar radiation injures the retinal skin. Taken together, the data indicate that science is fun for those who are open and ready to catch a winning form of per-

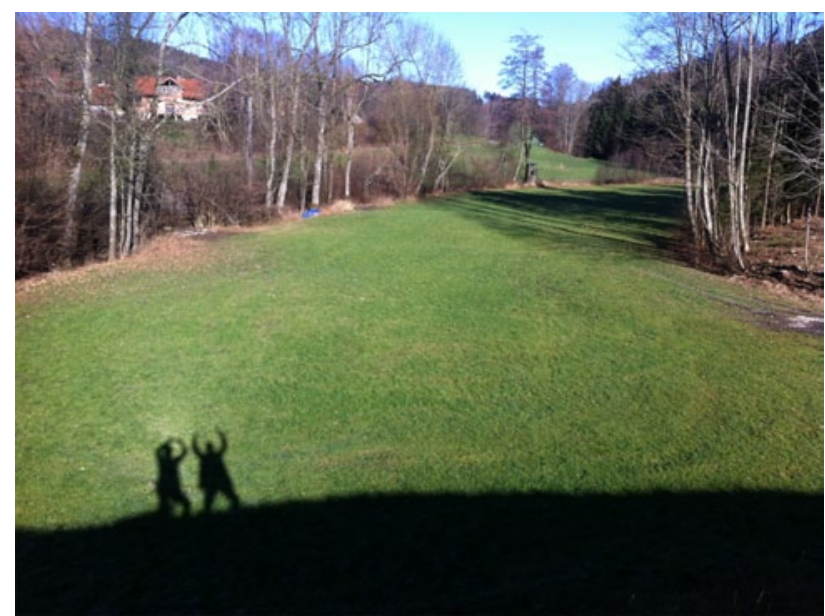

Fig. 3 The image cartoons the idea of the author, that shadows hide the perception of a given truth and thus contribute to outbalance and direct our awareness within the spectrum of light, as described in the text. Image obtained in Zell am Pettenfirst, Upper Austria (November 2015)

ception. Let us sound through and become a person (i.e., latin per-sonare=sound through), a person, who cares. Here starts the mind-set of a physician. May the sun raise the flower to open a perfect smile to the world, your world, our world. May knowledge prosper and stream under the protective light of wisdom.

\section{Martin Riegler}

\section{Acknowledgements}

The author thanks the spectrum: his family, his producers, his friends, teachers, mentors, colleagues and neighbors, who motivate, stimulate, foster, and support his activities. In addition, the author thanks the readers, authors, and reviewers of European Surgery and the publisher to foster this fascinating central European academical project. Furthermore, the author expresses his gratitude for having been educated by the Medical University Austria including all its outstanding university clinics and affiliated institutions. Finally, the author wishes to continue his fruitful collaborations with the Medical Universities in Vienna, Graz, Innsbruck, Salzburg and all those institutions designed to become more than officially affiliated with our nation-wide academy in the future (i.e., Linz, St. Pölten, Klagenfurt).

\section{Conflict of interest}

The author declares that there exists no conflict of interest. 